\title{
PERAN WANITA USAHATANI TANAMAN HIAS TERHADAP PENDAPATAN KELUARGA MISKIN DI DESA TOLOMBUKAN KECAMATAN PASAN KABUPATEN MINAHASA TENGGARA
}

\author{
THE ROLE OF ORNAMENTAL PLANT FARMING WOMEN IN THE \\ INCOME OF POOR FAMILIES IN TOLOMBUKAN VILLAGE \\ PASAN DISTRICT SOUTHEAST MINAHASA REGENCY
}

\author{
Cristi S. Lumbu__(1), Juliana R. Mandei ${ }^{(2)}$, Charles R. Ngangi ${ }^{(2)}$
}

1) Mahasiswa Program Studi Agribisnis, Fakultas Pertanian, Universitas Sam Ratulangi, Manado

2) Dosen Program Studi Agribisnis, Fakultas Pertanian, Universitas Sam Ratulangi, Manado

*Penulis untuk korespondensi: lumbuchristy@gmail.com

Naskah diterima melalui e-mail jurnal ilmiah agrisosioekonomi@unsrat.ac.id : Selasa, 6 April 2021

Disetujui diterbitkan

: Jumat, 28 Mei 2021

\begin{abstract}
The purpose of this study was to determine the role of ornamental plant farming women in poor families in Tolombukan Village, Pasan District, Southeast Minahasa Regency. The research was conducted for three months, from December to February 2020. The data used are primary data obtained through interviews with 20 women who are farming ornamental plants. Secondary data were obtained from the Tolombukan Village Office. The data analysis used is descriptive, contribution formula and the data is presented in tabular form. The role of women as main breadwinners if it has greater than 50 percent. The results showed that the role of women as wives who cultivated ornamental plants in Tolombukan Village was as additional breadwinners and not the main breadwinners for their families.-
\end{abstract}

Keywords: role of women; family income; Tolombukan Village

\begin{abstract}
ABSTRAK
Tujuan penelitian ini yaitu untuk mengetahui peran wanita usahatani tanaman hias terhadap keluarga miskin di Desa Tolombukan, Kecamatan Pasan, Kabupaten Minahasa Tenggara. Penelitian dilaksanakan selama tiga bulan yaitu dari bulan Desember sampai Februari tahun 2020. Data yang digunakan adalah data primer yang diperoleh melalui wawancara kepada 20 wanita usahatani tanaman hias. Data sekunder diperoleh dari Kantor Desa Tolombukan. Analisis data yang digunakan yaitu deskriptif dan data disajikan dalam bentuk table dan menggunakan rumus kontribusi. Peran perempuan sebagai pencari nafkah utama bila lebih besar dari 50 persen. Hasil penelitian menunjukkan bahwa peran wanita sebagai istri yang berusahatani tanaman hias di Desa Tolombukan ini adalah sebagai pencari nafkah tambahan dan bukan pencari nafkah utama bagi keluarganya.
\end{abstract}

Kata Kunci: Peran Wanita; Pendapatan Keluarga; Desa Tolombukan 


\section{PENDAHULUAN}

\section{Latar Belakang}

Besarnya peranan pertanian di Indonesia memberikan motivasi pedesaan untuk memiliki lahan pertanian yang dapat dijadikan sebagai sumber produksi. Oleh karena itu, mereka berupaya dengan berbagai cara untuk memenuhi lahan pertanian baik yang ada di wilayah tempat tinggalnya maupun di luar desa. Masyarakat petani yang kehidupannya tergantung pada tanah sebagai sarana produksi mengalami kesulitan dalam menjalani hidup, dalam hal ini adalah kesejahteraan ekonomi. Tak jarang kita dapatkan petani di desa-desa berada dalam garis kemiskinan. Hal ini disebabkan meningkatnya berbagai kebutuhan hidup, baik kebutuhan sekunder maupun primer dan juga karena terjadinya krisis ekonomi yang tak kunjung terselesaikan, inilah yang membuat para petani miskin semakin kewalahan dalam memperbaiki perekonomian keluargannya. Menurut Munandar (1985) peran wanita bukan saja hanya bekerja di dalam rumah tangganya, yaitu melayani, seperti mendidik, merawat, mengatur untuk dinikmati oleh orang lain atau menikmati bersama-sama dengan orang lain, tetapi juga bekerja, yaitu melakukan kegiatan yang memberikan penghasilan untuk kebutuhan keluarga.

Dalam hal ini dapat dilihat pada kondisi wanita di Desa Tolombukan, dimana ibu-ibu rumah tangga turut berpartisipasi langsung dalam hal mencari nafkah dengan berusahatani tanaman hias. Rendahnya pendapatan laki-laki yang menjadi kepala keluarga mendorong mereka untuk bekerja menaikkan pendapatan dalam memenuhi kebutuhan keluarga yang dirasa tidak mencukupi. Karena kondisi ini juga pemerintah menyelenggarakan penyaluran Bansos Beras Sejahtera (RASTRA), sasaran Bansos Rastra adalah keluarga dengan kondisi sosial ekonomi $25 \%$ terendah di wilayah kabupaten/kota. Berdasarkan data yang diperoleh, jumlah penerima Bansos Rastra di Desa Tolombukan sebanyak 43 keluarga (Kantor Desa Tolombukan, 2019). Data tersebut yang menjadi populasi dalam penelitian ini dan selanjutnya responden yang diambil adalah wanita yang masih bersuami dan berusahatani tanaman hias, dan diperoleh sebanyak 20 reponden.

Dari hasil wawancara dengan responden, tanaman hias di Desa Tolombukan sudah berkembang sekitar tahun 2000an dengan berbagai macam jenis tanaman hias, namun berdasarkan survey yang dilakukan dilapangan terdapat 4 jenis tanaman hias yang paling banyak terjual yaitu tanaman puring, bougenville, palem dan cobra (peace lily). Harga yang dipatok untuk jenis tanaman tersebut bervariasi antara Rp.5.000 sampai Rp.15.000 untuk tanaman dalam polybag dan Rp.25.000 sampai Rp.35.000 untuk tanaman yang sudah dipindahkan ke dalam pot. Ibu-ibu di Desa Tolombukan rata-rata memanfaatkan pekarangan untuk usahatani sendiri, juga tidak perlu susah-susah memasarkan tanaman mereka karena pedagang pengumpul yang akan datang langsung ke lokasi dan mengangkut tanaman hias menggunakan mobil pickup sehingga tidak memerlukan sewa tempat dan tidak membutuhkan modal yang besar.

\section{Konsep Peran \\ Menurut Kamus Bahasa Indonesia pengertian peran adalah sesuatu yang} menciptakan bagian yang memegang pimpinan atau kekuasaan terutama dalam terjadinya suatu hal ataupun peristiwa. Sedangkan menurut Soekanto dalam Nurmayasari (2014) peran adalah segala sesuatu oleh seseorang atau kelompok orang dalam melakukan sesuatu kegiatan karena kedudukan yang dimilikinya. Sedangkan menurut Astuti (2013) peran adalah keikutsertaan individu atau kelompok dalam suatu kegiatan guna mencapai tujuan individu maupun tujuan bersama. Peran yang terdapat antara pria dan wanita itu tidak dapat ditentukan karena antara keduanya terdapat perbedaan biologis dan kodrat, tetapi dibedakan atau dipilih-pilih menurut kedudukan, fungsi dan peranan masing-masing dalam berbagai bidang kehidupan dan pembangunan. Astuti (2013) menyebutkan bahwa suatu peranan paling sedikit mencakup tiga hal, yaitu :

a. Peranan meliputi norma-norma yang dihubungkan dengan posisi atau tempat seseorang dalam masyarakat. Peranan dalam arti ini merupakan rangkaian peraturanperaturan yang membimbing seseorang dalam kehidupan bermasyrakat.

b. Peran adalah suatu konsep perihal apa yang dapat dilakukan individu dalam masyrakat sebagai organisasi.

c. Peran juga dapat dikatakan sebagai perikelakuan individu yang penting bagi struktur sosial masyarakat.

Dari beberapa pengertian uraian di atas maka dapat disimpulkan peranan merupakan suatu konsep tentang apa yang dapat dilakukan oleh individu dalam masyarakat sebagai organisasi. Peranan juga dapat dikatakan sebagai perilaku individu yang penting bagi struktur sosial masyarakat. 


\section{Peran Wanita}

Peran adalah bagian yang dimainkan seseorang pada setiap keadaan dan cara bertingkahlaku untuk menyelaraskan diri dengan keadaan (Tobing, 2009). Dalam hal ini, menurut Sajogyo (1983) dalam Luthfi (2010) peranan perempuan dapat dianalisis dalam dua cara yaitu :

1. Dalam status atau kedudukannya sebagai ibu rumah tangga, wanita melakukan pekerjaan rumah tangga sebagai bagian dari proses reproduktif yaitu suatu pekerjaan yang tidak langsung menghasilkan pendapatan tetapi memungkinkan anggota rumah tangga yang lain untuk melakukan pekerjaan mencari nafkah.

2. Pada posisi sebagai pencari nafkah (tambahan atau pokok) wanita melakukan pekerjaan produktif yang langsung menghasilkan pendapatan.

\section{Peran dan Kedudukan Wanita}

Peranan merupakan aspek yang dinamis dari kedudukan. Apabila seseorang melaksanakan hak-hak dan kewajiban-kewajiban sesuai dengan kedudukannya maka dia menjalankan suatu peranan. Perbedaan antara kedudukan dengan peranan, adalah untuk kepentingan ilmu pengetahuan, keduanya tak dapat dipisahpisahkan, oleh karena yang satu tergantung pada yang lain dan sebaliknya juga demikian, tak ada peranan tanpa kedudukan atau kedudukan tanpa peranan (Sukirman, 2013). Kedudukan wanita sebagai makhluk individu dan sosial, berarti wanita mempunyai hak dan dapat menentukan kehendak menurut pribadinya. Wanita lebih mengerti akan dirinya dan menyadari perannya bahwa, dirinya mampu dan dapat bekerja dalam membantu kehidupan rumah tangganya. Peran wanita dalam keluarga dengan melakukan pekerjaan rumah tangga seperti memasak, mengasuh anak, melayani suami, merupakan suatu kegiatan produktif yang secara tidak langsung menambah pendapatan keluarga.

Menurut Siagian (1984) dalam Aswiyati (2016) peran perempuan di pedesaan dibagi dalam dua bagian yaitu: Pertama sebagai istri atau ibu rumah tangga, dimana mereka melakukan pekerjaan rumah tangga yang tidak menghasilkan pendapatan secara langsung tetapi tidak memungkinkan anggota keluarga lain melakukan pekerjaan mencari nafkah. Kedua, membantu untuk mencari nafkah dalam kehidupan keluarga sehari-hari dimana biasanya perempuan di desa mendapingi suami bekerja untuk mencari nafkah. Tujuan hidup keluarga, yaitu kebahagian lahir dan batin yang dapat dicapai dengan dilandasi kecintaan dari kedua belah pihak, ada toleransi, jujur dan terus terang. Laki-laki dan perempuan sebagai makhluk terikat satu sama lain, karena itu suami harus mempunyai keseragaman, untuk menghadapi masalah dalam keluarga.

\section{Usahatani Tanaman Hias}

Suratiyah (2006) menyatakan bahwa ilmu usahatani adalah ilmu yang mempelajari bagaimana seseorang mengusahakan dan mengkoordinir faktor-faktor produksi yang berupa lahan dan alam sekitarnya sebagai modal sehingga memberikan manfaat yang sebaikbaiknya. Tanaman hias merupakan tanaman bunga-bungaan yang terbentuk unik dan khas yang digunakam sebagai dekorasi atau hiasan, baik dalam maupun luar ruangan untuk memperindah, mempercantik serta memiliki nilai lebih dari tanaman lainnya (Hapsari, 2015)

Usahatani skala keluarga membuat peran setiap anggota keluarga yang terkait dalam kegiatan usahatani menjadi penting. Khususnya peran seorang wanita tani dalam kegiatan usahatani, biasanya memiliki peran ganda dalam menjalankan usahatani dan menjalankan perannya dalam kegiatan rumah tangga. Beberapa kegiatan dalam usahatani banyak atau bahkan hanya melibatkan perempuan dalam pelaksanaannya. Oleh karena itu, keberhasilan usahatani juga ditentukan dari seberapa besar peran seorang wanita dalam kegiatan usahatani tanaman hias serta faktor-faktor yang berpengaruh terhadap peran wanita tani dalam usahatani tanaman hias.

\section{Hal-hal yang Mendorong Wanita untuk Bekerja}

1. Kemiskinan

Kalangan pemerhati masalah
kemiskinan telah mencoba memilah
kemiskinan ke dalam empat bentuk, yaitu
kemiskinan absolut, kemiskinan relatif,
kemiskinan struktural, dan kemiskinan kultural
(Ngangi, 2008). Kemiskinan Absolut, yaitu
apabila tingkat pendapatannya dibawah garis
kemiskinan atau sejumlah pendapatan yang
tidak cukup untuk memenuhi kebutuhan
minimum yaitu kebutuhan pangan, sandang,
kesehatan, perumahan, dan pendidikan.
Kemiskinan Relatif, yaitu dimana pendapatan
berada diatas garis kemiskinan, namun relatif
lebih rendah dibanding masyarakat sekitar.


Kemiskinan Struktural, adalah kondisi atau situasi miskin karena pengaruh kebijakan pembangunan yang belum menjangkau seluruh masyarakat sehingga menyebabkan kemiskinan pada pendapatan. Kemiskinan Kultural, mengacu pada persoalan sikap seseorang atau masyarakat yang disebabkan oleh faktor budaya, seperti tidak mau memperbaiki kehidupan, malas, pemboros, dan tidak kreatif.

Pengukuran garis kemiskinan terdiri dari Garis Kemiskinan Makanan (GKM) dan Garis Kemiskinan Non Makanan (GKNM). Pada September 2018 GKM Sulawesi Utara sebesar Rp. 275.123 per kapita per bulan, sedangkan GKNM sebesar Rp. 81.783 per kapita per bulan. Hal ini menunjukkan bahwa konsumsi makanan menjadi hal yang utama bagi pemenuhan kebutuhan penduduk miskin (BPS, 2018).

2. Adanya kebutuhan pokok rumah tangga yang harus dipenuhi

Evers dan Sumardi (1985) dalam Dewi dan Wulandari (2013) menyatakan bahwa manusia selalu ingin memenuhi kebutuhan hidupnya baik moral maupun material, baik kebutuhan pokok juga kebutuhan lain meskipun tidak sesuai dengan kemampuan mereka. Kebutuhan pokok atau kebutuhan dasar dapat dijelaskan sebagai kebutuhan yang sangat penting guna kelangsungan hidup manusia, baik yang terdiri dari kebutuhan atau konsumsi individu (makan, perumahan, pakaian) maupun keperluan pelayanan sosial tertentu (air minum, transportasi, sanitasi dan pendidikan).

\section{Program Beras Sejahtera (Rastra)}

Untuk mengurangi beban pengeluaran rumah tangga miskin akibat krisis ekonomi tahun 1997/1998, Pemerintah Indonesia melaksanakan subsidi beras untuk pemenuhan sebagian kebutuhan bahan pangan masyarakat miskin. Program subsidi beras bagi masyarakat berpendapatan rendah yang dikenal dengan nama Rastra (Beras Sejahtera) ini disalurkan setiap bulan dengan alokasi sebesar 15 kg untuk setiap Rumah Tangga, sasaran Penerima Manfaat (RTS-PM) dengan harga tebus Rastra sebesar Rp1.600, - /kg (TNP2K, 2018)

Program Bansos Rastra bertujuan untuk mengurangi beban pengeluaran dan meningkatkan akses masyarakat miskin dan rentan dalam pemenuhan kebutuhan pangan pokok (dalam hal ini beras) yang menjadi hak dasarnya.

\section{Pendapatan}

Pendapatan merupakan suatu hasil yang diterima oleh seseorang atau rumah tangga dari berusaha atau bekerja. Jenis masyarakat bermacam ragam, seperti bertani, nelayan, beternak, buruh, serta berdagang dan juga bekerja pada sektor pemerintah dan swasta (Nazir, 2010: 17)

Pendapatan wanita dipengaruhi oleh karakteristik sosial ekonomi yaitu umur, tingkat pendidikan, pengalaman bekerja, jumlah tanggungan dan curahan tenaga kerja, karena wanita semakin dituntut peranannya bukan hanya sebagai ibu rumah tangga melainkan juga sebagai orang yang berperan dalam menyumbangkan pendapatan pada keluarga. Kontribusi penghasilan wanita dalam ekonomi keluarga ialah bagian penghasilan yang disumbangkan wanita dari seluruh jumlah pendapatan keluarga (Ambarini, 2002 dalam Bertham,dkk, 2011).

Menurut Astutik (2013) pendapatan rumah tangga adalah pendapatan yang diperoleh dari seluruh anggota rumah tangga keluarga baik yang berasal dari kepala keluarga atau seluruh anggota keluarga. Jumlah tanggungan yang tinggi pada suatu rumah tangga tanpa diikuti dengan peningkatan dari segi ekonomi akan mengharuskan anggota keluarga selain kepala keluarga untuk mencari nafkah. Pendapatan keluarga ialah sejumlah penghasilan dari keluarga (penghasilan dari suami, istri, dan anggota keluarga lainnya) (Simanjuntak, 2001).

Mempertimbangkan pentingnya peran wanita dalam memenuhi kebutuhan keluarga, maka kondisi tersebut menarik minat peneliti untuk mengkaji lebih dalam mengenai peran wanita usahatani tanaman hias terhadap pendapatan keluarga miskin di Desa Tolombukan Kecamatan Pasan Kabupaten Minahasa Tenggara.

\section{Rumusan Masalah}

Berdasarkan latar belakang yang telah dikemukakan, maka yang menjadi rumusan masalah dalam penelitian ini yaitu, berapa sumbangan wanita usahatani tanaman hias terhadap keluarga miskin di Desa Tolombukan Kecamatan Pasan Kabupaten Minahasa Tenggara?

\section{Tujuan Penelitian}

Tujuan penelitian ini yaitu untuk mengetahui peran wanita usahatani tanaman hias terhadap keluarga miskin di Desa Tolombukan Kecamatan Pasan Kabupaten Minahasa Tenggara. 


\section{Manfaat Penelitian}

Manfaat dari penelitian ini yaitu :

1. Meningkatkan pengetahuan tentang peran wanita usahatani tanaman hias terhadap pendapatan keluarga miskin di Desa Tolombukan Kecamatan Pasan.

2. Diharapkan bagi peneliti yang memiliki minat yang sama mendapat pengetahuan tentang peran wanita usahatani tanaman hias terhadap pendapatan keluarga miskin.

3. Menjadi bahan studi bagi peneliti-peneliti selanjutnya dan juga referensi dalam melaksanakan penelitian.

4. Diharapkan menjadi bahan pertimbangan bagi penentu kebijakan demi meningkatkan mutu pendidikan.

\section{METODE PENELITIAN}

\section{Waktu dan Tempat Penelitian}

Penelitian ini dilaksanakan selama tiga bulan yaitu dari bulan Desember 2019 sampai Februari 2020, mulai dari persiapan sampai penyusunan laporan penelitian. Tempat penelitian dilaksanakan di Desa Tolombukan Kecamatan Pasan.

\section{Metode Pengumpulan Data}

Metode pengumpulan data dalam penelitian ini, dengan cara mengambil data primer dan data sekunder. Data primer adalah data yang diperoleh secara langsung dari lapangan melalui wawancara dengan menggunakan daftar pertanyaan kepada wanita usahatani tanaman hias. Sedangkan data sekunder adalah data yang diperoleh dari kantor desa.

\section{Metode Pengambilan Sampel}

Populasi dalam penelitian ini yaitu keluarga penerima RASTRA (beras sejahtera). Pengambilan sampel menggunakan metode (purposive sampling), purposive memilih wanita yang masih bersuami dan berusahatani tanaman hias. Sampel di ambil sebanyak 20 Responden.

\section{Konsep Pengukuran Variabel}

1. Karakteristik responden
a. Umur responden (Tahun)
b. Pendidikan (SD, SMP, SMA)
c. Jumlah Tanggungan Keluarga (Total keseluruhan anggota keluarga)

2. Pendapatan keluarga: Pendapatan Istri Rp/bulan, pendapatan suami Rp/bulan, pendapatan anak Rp/bulan.

3. Besarnya pendapatan IRT terhadap pendapatan keluarga yang dinyatakan dalam persentase.

\section{Metode Analisis Data}

Metode analisis data yang digunakan dalam penelitian ini adalah metode deskriptif, dimana data di sajikan dalam bentuk tabel.

Untuk mengetahui besarnya pendapatan istri terhadap pendapatan keluarga digunakan rumus: Kontribusi $=\frac{X 1}{X 2} \times 100 \% \ldots \ldots . . .($ Zulfikri dkk, 2014)

$$
\begin{aligned}
\text { Dimana: } & \mathrm{X} 1=\text { Pendapatan dari usahatani } \\
\mathrm{X} 2 & =\text { Totaman Pendapatan keluarga }
\end{aligned}
$$

Tabel 1. Skala Interval

\begin{tabular}{cc}
\hline Persentase & Kriteria \\
\hline $0,00-10,00 \%$ & Sangat rendah \\
$10,01-20,00 \%$ & Rendah \\
$20,01-30,00 \%$ & Sedang \\
$30,01-40,00 \%$ & Tinggi \\
$>50 \%$ & Paling tinggi \\
\hline Sumber Data : Zulkifri dkk, 2014 &
\end{tabular}

Selanjutnya, skala interval digunakan untuk menentukan istri sebagai pencari nafkah utama $(>50 \%)$ atau pencari nafkah tambahan $(<50 \%)$.

\section{HASIL DAN PEMBAHASAN}

\section{Deskripsi Wilayah Penelitian}

Tolombukan merupakan salah satu desa yang berada di Kecamatan Pasan, Kabupaten Minahasa Tenggara, Provinsi Sulawesi Utara, Indonesia. Desa ini terletak di bagian utara pulau Sulawesi. Desa Tolombukan berada pada ketinggian $500 \mathrm{~m}$ dari permukaan laut dengan suhu makimum $20^{\circ} \mathrm{C}-30^{\circ} \mathrm{C}$. Dengan batas-batas sebagai berikut :

Sebelah Utara : Desa Tolombukan Satu

Sebelah Selatan : Desa Maulit

Sebelah Timur : Desa Liwutung

Sebelah Barat : Desa Tolombukan Barat

\section{Karakteristik Responden}

Karakteristik responden dalam penelitian ini terdiri dari umur, tingkat pendidikan dan jumlah tanggungan keluarga.

\section{Umur Responden}

Umur sangat mempengaruhi kemampuan seseorang baik dalam cara berfikir maupun bekerja. Umur yang produktif adalah pada usia 16 sampai 60 tahun, jika diatas 60 tahun maka usia fisik petani semakin menurun dan produktifitas dalam usahatani makin berkurang. Menurut penelitian yang sudah dilakukan umur responden dapat dilihat pada Tabel 2. 
Tabel 2. Responden menurut Kelompok Umur di Desa

\begin{tabular}{cccc} 
Tolombukan & & \\
\hline No. & $\begin{array}{c}\text { Umur } \\
\text { (Tahun) }\end{array}$ & $\begin{array}{c}\text { Jumlah } \\
\text { (Orang) }\end{array}$ & $\begin{array}{c}\text { Persentase } \\
(\boldsymbol{\%})\end{array}$ \\
\hline 1. & $39-50$ & 12 & $60 \%$ \\
2. & $51-60$ & 4 & $20 \%$ \\
3. & $61-70$ & 3 & $15 \%$ \\
4. & $>69$ & 1 & $5 \%$ \\
\hline & Total & $\mathbf{2 0}$ & $\mathbf{1 0 0}$ \\
\hline
\end{tabular}

Sumber Data : Diolah dari Data Primer, 2020

Hasil penelitian menunjukan bahwa sebagian besar responden berada pada usia produktif, yaitu umur 39-50 tahun sebanyak $60 \%$, diikuti kelompok umur 51-60 tahun sebanyak 20\%, kelompok 61-70 tahun tercatat sebanyak $15 \%$, sedangkan untuk kelompok umur $>69$ tahun yaitu $5 \%$.

\section{Pendidikan Responden}

Pendidikan sangat penting dalam usaha peningkatan kualitas seseorang karena berguna dalam pembangunan pribadi serta peningkatan intelektual dan wawasan seseorang.

Tabel 3. Jumlah Responden Menurut Tingkat Pendidikan

\begin{tabular}{cccc}
\hline No. & Pendidikan & $\begin{array}{c}\text { Jumlah } \\
\text { (Orang) }\end{array}$ & $\begin{array}{c}\text { Persentase } \\
(\mathbf{\%})\end{array}$ \\
\hline 1. & SD & 12 & $60 \%$ \\
2. & SMP & 4 & $20 \%$ \\
3. & SMA & 4 & $20 \%$ \\
\hline & Total & $\mathbf{2 0}$ & $\mathbf{1 0 0}$ \\
\hline
\end{tabular}

Sumber Data : Diolah dari Data Primer, 2020

Tabel 3 menunjukkan persentase pendidikan terbesar yaitu $60 \%$ ada pada tingkat Pendidikan SD, dan persentase terendah atau paling sedikit ada pada tingkat Pendidikan SMP dan SMA yaitu 20\%. Dari penelitian ini dapat diketahui bahwa responden menjalankan kegiatan tanaman hias cukup lama. Dengan pengalaman inilah responden tidak memerlukan pendidikan yang tinggi, hanya membutuhkan kemampuan dan keterampilan menanam dalam menjalankan kegiatan tersebut.

\section{Jumlah Tanggungan Keluarga}

Jumlah tanggungan keluarga adalah banyaknya anggota keluarga yang terdiri dari anak serta orang lain yang turut serta dalam keluarga atau hidup dalam satu rumah dan makan bersama yang menjadi tanggung jawab kepala keluarga. Jumlah tanggungan keluarga mempengaruhi pendapatan per kapita. Makin banyak tanggungan suatu keluarga makin besar biaya yang harus dikeluarkan, makin sedikit tanggungan keluarga makin sedikit juga biaya yang dikeluarkan. Tanggungan keluarga merupakan salah satu alasan utama bagi para ibu rumah tangga turut serta dalam membantu suami dan memutuskan untuk bekerja memperoleh penghasilan.

\begin{tabular}{cccc}
\multicolumn{4}{c}{ Tabel 4. Jumlah Tanggungan Kelurga } \\
\hline No & $\begin{array}{c}\text { Jumlah } \\
\text { tanggungan } \\
\text { (orang) }\end{array}$ & $\begin{array}{c}\text { Jumlah } \\
\text { Responden }\end{array}$ & $\begin{array}{c}\text { Jumlah } \\
\text { tanggungan } \\
\text { (orang) }\end{array}$ \\
\hline 1. & 2 & 5 & $25 \%$ \\
2. & 3 & 5 & $25 \%$ \\
3. & 4 & 6 & $30 \%$ \\
4. & 5 & 4 & $20 \%$ \\
\hline & Total & $\mathbf{2 0}$ & $\mathbf{1 0 0}$ \\
\hline
\end{tabular}

Sumber Data : Diolah dari Data Primer, 2020

Hasil penelitian menunjukkan responden rata-rata mempunyai jumlah anggota keluarga sebanyak tiga orang dengan kisaran 2 sampai dengan 5 orang, dapat dilihat pada Tabel 7. Jumlah tanggungan responden yang memiliki jumlah responden terbanyak yaitu 4 tanggungan, dengan persentase $30 \%$, diikuti jumlah tanggungan 2 dan 3 orang yaitu $25 \%$ dan terakhir yang memiliki jumlah responden paling sedikit yaitu 5 tanggungan dengan persentase $20 \%$.

\section{Peran Wanita Usahatani Tanaman Hias dalam Keluarga}

Total pendapatan keluarga didapat dari pendapatan setiap anggota keluarga yang terdiri dari pendapatan suami, istri, dan pendapatan anak yang sudah bekerja. Masing-masing anggota keluarga memegang peranan dalam meningkatkan pendapatan guna untuk memperbaiki kesejahteraan keluarga. Pendapatan dari masingmasing anggota keluarga selanjutnya akan dijelaskan oleh tabel-tabel berikut.

Tabel 5. Pendapatan Istri dari Usahatani Tanaman Hias (Rp/bulan)

\begin{tabular}{ccc}
\hline Pendapatan & $\begin{array}{c}\text { Jumlah } \\
\text { (orang) }\end{array}$ & $\begin{array}{c}\text { Persentase } \\
(\boldsymbol{\%})\end{array}$ \\
\hline $200.000-250.000$ & 16 & 80 \\
$>250.000$ & 4 & 20 \\
\hline Jumlah & $\mathbf{2 0}$ & $\mathbf{1 0 0}$
\end{tabular}

Sumber Data : Diolah dari Data Primer, 2020

Berdasarkan data yang disajikan pada Tabel 8 , persentase terbanyak ada pada tingkat pendapatan Rp. 200.000 sampai Rp. 250.000 yaitu sebanyak $80 \%$. Persentase terkecil ada pada tingkat pendapatan >Rp. 250.000 yaitu sebanyak $20 \%$. Perbedaan pendapatan ini dipengaruhi oleh banyak tidaknya pesanan dan kebutuhan. Responden tidak memiliki pendapatan diluar dari usahatani tanaman hias karena mereka tidak memiliki pekerjaan sampingan. Pendapatan responden diakui digunakan untuk keperluan rumah tangga mulai dari kebutuhan makan, sekolah anak, tabungan sampai kebutuhan lainnya.

Suami juga berperan terhadap pendapatan di dalam keluarga. Yang menjadi aspek dalam penelitian ini yaitu yang mempunyai pekerjaan. 
Tabel 6. Distribusi Pendapatan Suami (Rp/bulan)

\begin{tabular}{ccc}
\hline Pendapatan & $\begin{array}{c}\text { Jumlah } \\
\text { (orang) }\end{array}$ & $\begin{array}{c}\text { Persentase } \\
(\boldsymbol{\%})\end{array}$ \\
\hline $300.000-500.000$ & 13 & 65 \\
$>500.000-1.000 .000$ & 7 & 35 \\
\hline Jumlah & $\mathbf{2 0}$ & $\mathbf{1 0 0}$ \\
\hline
\end{tabular}

Sumber Data : Diolah dari Data Primer, 2020

Tabel 9 menunjukkan sebanyak $65 \%$ suami memiliki pendapatan Rp. 300.000-500.000/bulan. Umumnya suami pada kelas ini bekerja sebagai buruh tani dan tukang yang kadang tidak memperoleh pendapatan dalam 1 hari. Selanjutnya, sebanyak 35\% suami dengan pendapatan Rp. 500.000-Rp. 1.000.000/bulan. Suami pada kelas ini bekerja sebagai petani.

Pendapatan suami dibandingkan dengan pendapatan responden (istri), pendapatan yang lebih banyak itu dihasilkan dari pendapatan suami sebagai petani. Jadi dapat dikatakan bahwa suami adalah pencari nafkah utama dalam keluarga.

Anggota lain dalam keluarga juga berperan dalam memenuhi kebutuhan hidup sehari-hari. Dalam hal ini yang dimaksud dengan anggota keluarga yaitu orang yang ada dalam keluarga. Selain responden dan suami, yang sudah memperoleh penghasilan sendiri yaitu anak. Pendapatan anggota keluarga diperlukan untuk dapat melihat perbandingannya dengan pendapatan responden. Berikut adalah data anak dari responden.

Tabel 7. Distribusi Pendapatan Anak (Rp / bulan)

\begin{tabular}{ccc}
\hline Pendapatan & $\begin{array}{c}\text { Jumlah } \\
\text { (orang) }\end{array}$ & $\begin{array}{c}\text { Persentase } \\
(\boldsymbol{\%})\end{array}$ \\
\hline- & 18 & 90 \\
1.000 .000 & 2 & 10 \\
\hline Jumlah & $\mathbf{2 0}$ & $\mathbf{1 0 0}$ \\
\hline
\end{tabular}

Sumber Data : Diolah dari Data Primer, 2020

Tabel 10 menunjukkan banyaknya anak responden yang tidak memiliki pendapatan sebanyak 90\%. Tidak adanya pendapatan dikarenakan mereka belum cukup umur atau masih menempuh pendidikan dan sedang mencari pekerjaan. Anak dengan pendapatan Rp. 1.000 .000 sebulan hanya $10 \%$. Usia anak yang bekerja sudah pada usia produktif dan bekerja sebagai swasta merupakan lulusan SMA.

Dalam penelitian ini pendapatan keluarga berasal dari tiga sumber, yaitu dari kepala keluarga (suami), dari responden/istri (usaha tanaman hias), dan anak (yang sudah bekerja).
Tabel 8. Pendapatan Anggota Keluarga Terhadap Total Pendapatan Keluarga

\begin{tabular}{cccc}
\hline $\begin{array}{c}\text { Anggota } \\
\text { Keluarga }\end{array}$ & $\begin{array}{c}\text { Total } \\
\text { Pendapatan } \\
(\mathbf{R p})\end{array}$ & $\begin{array}{c}\text { Rata-rata } \\
\text { Pendapatan }\end{array}$ & $\begin{array}{c}\text { Persentase } \\
(\mathbf{\%})\end{array}$ \\
\hline Suami & 11.400 .000 & 570.000 & 63,51 \\
Istri & 4.550 .000 & 227.500 & 25,35 \\
Anak & 2.000 .000 & 100.000 & 11,14 \\
\hline Jumlah & $\mathbf{1 7 . 9 5 0 . 0 0 0}$ & $\mathbf{8 9 7 . 5 0 0}$ & $\mathbf{1 0 0}$ \\
\hline
\end{tabular}

Sumber Data : Diolah dari Data Primer, 2020

Tabel 11 menunjukkan total keseluruhan pendapatan istri selama satu bulan sebesar Rp. 4.550.000 dengan rata-rata pendapatan setiap responden sebesar Rp. 227.500/ bulan. Total keseluruhan pendapatan keluarga selama satu bulan sebesar Rp. 17.950.000 dengan rata-rata pendapatan setiap keluarga sebesar Rp. 5.983.333/bulan. Berdasarkan data total pendapatan responden dan pendapatan keluarga, maka sumbangan pendapatan istri terhadap pendapatan keluarga adalah 25,35\%. Persentase pendapatan istri dari usahatani tanaman hias yaitu $25,35 \%$ atau rata-rata $\mathrm{Rp}$. $227.500 /$ bulan terhadap total pendapatan keluarga di Desa Tolombukan tergolong dalam kategori sedang. Yang dimaksud dengan sedang adalah istri di Desa Tolombukan ini dikategorikan sebagai pencari nafkah tambahan dan bukan pencari nafkah hidup utama keluarga.

\section{KESIMPULAN DAN SARAN}

\section{Kesimpulan}

Berdasarkan hasil penelitian, maka dapat disimpulkan bahwa peran istri yang berusahatani tanaman hias di Desa Tolombukan ini adalah sebagai pencari nafkah tambahan dan bukan pencari nafkah hidup utama keluarga.

\section{Saran}

1. Penelitian ini hendaknya dapat dijadikan bahan masukan bagi istri-istri untuk lebih dapat meningkatkan produktivitas, harus lebih pandai melihat peluang pasar, dan harus lebih memahami tentang pemasaran tanaman hias agar tidak lemah dalam persaingan usaha tanaman hias yang semakin hari semakin kuat.

2. Bagi pemerintah agar dapat menggelar sosialisasi supaya bisa memberikan keterampilan serta wawasan terhadap ibu-ibu yang berusahatani tanaman hias untuk kedepannya lebih dapat meningkatkan pendapatan dan kesejahteraan keluarga. 


\section{DAFTAR PUSTAKA}

Astuti, A. W. W. 2013. Peran Ibu Rumah Tangga Dalam Meningkatkan Kesejahteraan Keluarga (Doctoral Dissertation, Universitas Negeri Semarang).

Astutik, F. 2013. UPAYA PENINGKATAN PENDAPATAN RUMAH TANGGA MELALUI HOME INDUSTRY GAMBIR (KRUPUK KERTAS) DI DUSUN DUNENGENDAK DESA TLONTORAJA KECAMAN PASEAN KABUPATEN PAMEKASAN. Jurnal Pendidikan Ekonomi (JUPE).

Aswiyati, I. 2016. Peran Wanita Dalam Menunjang Perekonomian Rumah Tangga Keluarga Petani Tradisional Untuk Penanggulangan Kemiskinan Di Desa Kuwil Kecamatan Kalawat. HOLISTIK, Journal of Social and Culture.

Badan Pusat Statistik. 2018. PERKEMBANGAN TINGKAT KEMISKINAN. Provinsi Sulawesi Utara : Badan Pusat Statistik

Bertham, Y.H. 2011. Peranan Perempuan Dalam Perekonomian Keluarga Dengan Memanfaatkan Sumberdaya Pertanian. Jurnal AGRISEP. Jurusan Sosial Ekonomi Pertanian Fakultas Pertanian Universitas Bengkulu. Bengkulu.

Dewi, P. B., \& Wulandari, K. 2013. Gaya Hidup Masyarakat Nelayan.

Hapsari, R. D. 2015. Pola Perilaku Usaha Ekonomi Pedagang Tanaman Hias (Studi Kasus Di Blabak Kecamatan Mungkid Kabupaten Magelang) (Doctoral Dissertation, Universitas Negeri Semarang).

Luthfi, A.2010.Akses Dan Kontrol Perempuan Petani Penggarap Pada Lahan Pertanian PTPN IX Kebun Merbuh. Jurusan Sosiologi Dan Antropologi, Fakultas Ilmu Sosial, Universitas Negeri Semarang, Indonesia. Jurnal. Semarang.

Munandar, S. C. U. 1985. Emansipasi Dan Peran Perempuan. UI. Press Jakarta.
Nazir. 2010. "Analisis Determinan Pendapatan Pedagang Kaki Lima Di Kabupaten Aceh Utara." Tesis. Medan. Universitas Sumatera Utara.

Ngangi, C. 2008. Kemisknan Peluang Dan Tantangan. Jurusan Sosial Ekonomi Pertanian Unsrat.

Nurmayasari, D. 2014. Peran Anggota Kelompok Wanita Tani (KWT) “Laras Asri” Pada Peningkatan Kesejahteraan Keluarga (Studi Deskriptif Di Dusun Daleman Desa Kadirejo Kecamatan Pabelan Kabupaten Semarang) (Doctoral Dissertation, Universitas Negeri Semarang).

Simanjuntak, P. J. 2001. Pengantar Ekonomi Sumber Daya Manusia Edisi Kedua. Lembaga Penerbit Fakultas Ekonomi Universitas Indonesia. Jakarta.

Sukirman, N. 2013. Peran Perempuan Dalam Menanggulangi Kemiskinan Keluarga Di Gampong Teupin Peuraho Kecamatan Arongan Lambalek Kabupaten Aceh Barat(Doctoral Dissertation, Universitas Teuku Umar Meulaboh).

Suratiyah, K. 2006. Ilmu Usahatani. Penebar Swadaya. Jakarta.

Tim Nasional Percepatan Penanggulangan Kemiskinan. 2018. Pedoman Umum Bantuan Sosial Beras Sejahtera. Diakses Tanggal 18 Januari 2020 Http://Www.Tnp2k.Go.Id/Search?Q=Rast ra.

Tobing, E.J.,E. 2009. Peranan Tenaga Kerja Wanita Pada Usahatani Kopi Dan Sikapnya Terhadap Peran Ganda Dalam Rumah Tangga. Fakultas Pertanian. Universitas Sumatera Utara. Skripsi. Medan

Zulfikri., Dolorosa E., \& Komariyati., (2014). Analisis Kontribusi Usaha Ternak Sapi Potong Terhadap Pendapatan Rumah Tangga Petani Di Kecamatan Tebas Kabupaten Sambas. Skripsi Fakultas Pertanian Universitas Tanjungpura. 